\title{
Tipikalis Motif Kupu-Kupu dari Suku Enggros Papua
}

\author{
Nathalia Dwijayanti \\ Institut Seni dan Budaya Tanah Papua \\ Jl. Ki Hajar Dewantara No 19, Surakarta, Indonesia 57126 \\ e-mail: nathalia.dj29@gmail.com
}

Cite this article: Dwijayanti, Nathalia. 2019. "Tipikalis Motif Kupu-Kupu Dari Suku Enggros Papua”. Dewaruci: Jurnal Pengkajian dan Penciptaan Seni, Volume (14/2): 27-32.

\begin{abstract}
Batik is a cultural heritage of ancestors which is still developing. Batik in Indonesia has its own diversity and distinctive characteristics, including in the Papua region. In Papua batik has characteristics that describe animals, plants and musical instruments. In this study, the use of motifs in Enggros tribe has a different position from each of its clans. Some motifs in

the Enggros cannot be used by other clans. Each of these batik motifs has a meaning and

hereditary meaning. This study uses a review of the shape of the motif, colour, and aesthetic value. The research method uses a qualitative descriptive method supported by the hermeneutic theory as a method of obtaining a valid interpretation of objectivity. The results of this research discussion reveal about Enggros batik as a characteristic of the Enggros tribe whose surname is from the Iwo Tribe. Expectations achieved in this study can help and find out the motives of the Enggros and the community is expected to understand more deeply these motifs as a legacy of ancestral tradition.
\end{abstract}

Keywords: Batik, Motive, Tradition, Enggros

\section{Pendahuluan}

Motif merupakan suatu ornamen dalam batik, maka motif batik adalah gambar pada batik yang berupa perpaduan dalam batik yang berupa perpaduan antara garis, bentuk dan isen menjadi satu kesatuan bentuk yang membentuk satu unit keindahan (Sewan 1980). Terkait dengan hal tersebut menurut Murtihadi (1979: 71). Unsur-unsur ornamen motif batik dapat digolongkan menjadi tiga bagian pokok, yaitu (a). ornamen motif pokok atau utama, (b). pelengkap atau isisan motif, dan (c). isen-isen motif.

Penerapan motif sebagai ornamen pokok merupakan suatu corak dari batik sebagai pengisi bidang utama dan diselingi dengan ornamen tambahan. Pada umumnya ornamen utama ini mempunyai arti dan mengandung kejiwaan dari batik. Sedangkan ornamen tambahan merupakan pengisi bidang sehingga ada keluwesan antara ornamen pokok dan pengisi bidang utama yang harmonis.

Di Indonesia motif banyak sekali. Hal ini disebabkan banyaknya daerah yang menghasilkan batik dan macamnya yang banyak pula, sehingga bentuk motif batik itu walaupun menunjukkan persamaan tetapi cara penggubahan, penempatan, dan susunannya berbeda. Di samping itu perbedaan motif ini masih ada perbedaan antara aturan pemakaian dari tiap-tiap motif pada batik membagi motif batik menjadi 3 (tiga) 
bentuk, yaitu (1) stilasi (penggayaan, mengadakan perubahan bentuk yang lebih bergaya dengan tidak meninggalkan ciri-ciri asalnya), (2) distorsi (mengadakan perubahan bentuk dengan maksud menonjolkan sebagian unsur yang terkandung dalam suatu obyek (menonjolkan karakter, seperti pada wayang kulit), (3) dekoratif (menyederhanakan bentuk, (tidak memperhatikan atau memperhitungkan perspektif maupun 3 dimensi, cenderung ke arah hiasan) (Riyanto 1997). Menurut Murtihardi, bentuk-bentuk ornamen motif batik, dapat dibagi menjadi motif geometris, motif semen, motif buketan atau terang bulan, motif modern, motif pinggiran.

Susunan ornamen motif geometris ini dapat digolongkan menjadi motif banji, motif genggong, motif ceplokan, motif seperti anyaman, motif parang atau lereng, motif kawung. Susunan ornamen motif semen ini terdiri dari tumbuh-tumbuhan, burung, binatang, lar-laran (sayap) yang disusun dalam komposisi pembagian bidang yang harmonis. Motif semen ini dapat dibagi menurut golongannya, yaitu; (1) motif semen yang tersusun dari tumbuh-tumbuhan, (2) motif semenyang tersusun dari tumbuhtumbuhandan binatang, (3) motif semen yang tersusun dari gabungan antara tumbuhtumbuhan, binatang, dan lar-laran (sayap burung).

Susunan ornamen pada motif buketan atau terang bulan adalah motif bunga, dan tersusun seikat yang penempatannya tidak simetris dalam bidang lain. Susunan ornamen pada motif modern sebetulnya sedah mendekati kepada kebebasan mencipta dalam motif maupun pewarnaan. Adapun golongan motif pinggiran, susunan motif ini merupakan ornamen yang dipergunakan khusus untuk menghias tepi dari kain sebagai pemisah antara dua bidang (Murtihadi 1979).

\section{Warna}

Menurut Sulasmi Darma (Prawira 2002) warna adalah salah satu unsur keindahan dalam seni dan desain selain unsur-unsur visual lainnya seperti: garis, bidang, bentuk, tekstur, nilai, ukuran. Dalam buku yang sama ditambahkan oleh Wucius Wong menyebutkan bahwa warna termasuk yang Nampak atau visual. Warna dapat membedakan sebuah bentuk dari sekelilingnya, warna disini digunakan dalam arti yang luas, tidak hanya meliputi semua spektrum tetapi mencakup juga warna netral (hitam, putih dan deret abu-abu), dan segala ragam nada dan ronanya.

Karakteristik warna menurut Sulasmi Darma Prawira (Prawira 2002) adalah warna hangat, warna sejuk, warna tegas, warna berat, dan warna ringan. Warna hangat terdiri dari warna merah, kuning, cokelat, jingga. Penempatan warna-warna itu berada di dalam lingkungan warna-warna yang berbeda, terutama dari merah ke kuning. Warna sejuk adalah warna-warna dalam lingkaran warna yang terdiri dari hijau ke ungu melalui biru. Warna tegas terdiri atas warna biru, merah, kuning, putih, hitam. Sedangkan warna berat merupakan warna-warna tua yang mendekati warna hitam (cokelat tua, biru tua dan sebagainya). Adapun warna ringan terdiri atas warna-warna yang mendekati warna putih.

\section{Nilai Estetik}

Nilai Estetik sendiri mempunyai arti nilai dari suatu keindahan yang kita rasakan, setelah kita rasakan maka kita pun akan menilai keindahan objek tersebut. Nilai Estetik sangat dibutuhkan agar para seniman dapat menyajikan keindahan ketika mereka menampilkan dan menyajikan kepada para penikmat, dan juga bisa digunakan untuk layak atau tidaknya suatu seni untuk dipertontonkan kemasyarakat.

Nilai estetis identik dengan keindahan dan keunikan sebuah karya seni rupa. Nilai estetis sebuah karya seni rupa terutama dipengaruhi oleh keharmonisan dan keselarasan 
penataan unsur-unsur rupanya. Nilai estetis dapat juga bersifat subjektif sesuai selera orang yang melihatnya. Pengalaman pribadi, lingkungan dan budaya dimana seseorang tinggal dapat menyebabkan nilai estetis sebauh karya seni rupa berbeda antara satu orang dengan orang yang lainnya.

Nilai estetis obyektif memandang keindahan karya seni rupa berada pada wujud karya seni itu sendiri artinya keindahan tampak kasat mata. Sesungguhnya keindahan sebuah karya seni rupa tersusun dari komposisi baik, perpaduan warna yang cocok, penempatan obyek yang membentuk kesatuan dan sebagainya. Keselarasan dalam menata unsur-unsur visual inilah yang mewujudkan sebuah karya seni rupa.

Nilai estetis yang bersifat subyektif beranggapan keindahan tidak hanya pada unsur-unsur fisik yang diserap oleh mata secara visual, tetapi ditentukan oleh selera penikmatnya atau orang yang melihatnya. Sebagai contoh saat melihat sebuah karya seni lukis, seseorang dapat menemukan nilai estetis dari penataan unsur rupa pada karya itu. Sehingga orang tersebut merasa tertarik pada apa yang ditampilkan dalam karya itu dan merasa senang untuk terus melihatnya bahkan ingin memilikinya. walaupun orang lain mungkin tidak tertarik pada karya tersebut. Perbedaan inilah yang menunjukkan bahwa nilai estetis sebuah karya seni rupa dapat bersifat subyektif.

\section{Fungsi}

Batik di masa lalu dan masa sekarang memiliki fungsi yang berbeda seiring dengan berkembangnya zaman. Kalau pada zaman dahulu batik hanya digunakan sekedar menghadiri atau untuk perayaan upacara adat, lain halnya dengan batik masa kini yang dapat digunakan pada saat kapanpun, dimanapun dan dalam kesempatan apapun. Batik yang dulu terkesan formal kini mengfalami perkembangan dan semakin fashionable. Mengikuti perkembangan jaman, batik tidak lagi meninggalkan kesan yang kuno dan kaku. Kini, batik lebih fleksibel bisa digunakan untuk acara santai, jalan-jalan dan sekedar hangout.

Hal ini dikarenakan desain pakaian batik yang sudah lebih trendy dan fashionable sehingga menarik minat kaum muda untuk memakai batik disetiap kegiatan ataupun aktivitasnya. Selain itu juga batik selain berfungsi sebagai pakaian, batik sekarang berfungsi sebagai benda kerajinan seperti taplak meja, seprei, hiasan dinding, gorden, tas, kerudung dan sapu tangan. Berkembangnya inovasi dari batik ini membuat batik menjadi salah satu kegiatan ekonomi yang berpengaruh di Indonesia

\section{Pembahasan}

\section{Fungsi}

Kupu-kupu memiliki filosofi sebagai simbol pengetahuan serta dijadikan simbol kekuatan dan ketangguhan (Fitno 2015). Tidak banyak orang yang tahu bahwa manusia juga memiliki siklus hidup yang sama dengan kupu-kupu. Ada kelahiran, ada pertumbuhan yang dikuasai nafsu dan keegoisan, ada kematian sementara, kemudian kebangkitan yang mengagumkan. Kupu-kupu juga termasuk kedalam simbol jiwa dan keabadian. Kupu-kupu juga dianggap sebagai simbol Dewi Besar (Bunda Agung, Magna Mater). Gambar Dewi Besar kembali ke zaman kuno sejarah manusia, ke Paleolitik. Dewa tertinggi ini melambangkan surga dan bumi pada saat yang sama, hidup dan mati. Burung dan serangga terbang dikaitkan dengan dewi besar. Salah satu serangga yang mewakili sang dewi adalah seekor kupu-kupu. Karena kepercayaan bahwa penyihir dapat berubah menjadi kupu-kupu, kupu-kupu berkontribusi pada konsepsi dan perang bayang-bayang. 
Bagi orang Jepang, kupu-kupu melambangkan seorang wanita muda, sementara kupu-kupu yang saling berkibar menandakan kebahagiaan pernikahan. Kupu-kupu putih adalah roh orang mati. Masyarakat Mexico beranggapan kupu-kupu memiliki atribut dewa vegetasi, musim semi dan cinta, "Pangeran Bunga" Xochipilla. Dikaitkan dengan matahari dan merupakan simbol api yang melambai. Dipotong dengan pisau batu (itzli), kupu-kupu adalah dewi Itzpapalotl, kupu-kupu Obsidian, roh malam bintang-bintang yang menyala dan lambing-lambang jiwa wanita yang mati saat melahirkan. Yunani kuno menganggap kupu-kupu sebagai simbol keabadian jiwa. Psche yang namanya berarti "jiwa", muncul sebagai seorang gadis dengan sayap kupu-kupu.

Dalam kekristenan tahap perkembangan kupu-kupu melambangkan kahidupan, kematian, kebajikan, oleh karena itu kupu-kupu ini kadang-kadang digambarkan di tangan bayi Kristus, yang melambangkan kelahiran kembali dan kebangkitan jiwa. Dalam lukisan-lukisan yang menggambarkan kehidupan di surga, sayap-sayap semacam itu ditemukan dalam jiwa, yang ditempatkan Sang Pencipta dalam tubuh Adam.

\section{Motif Kupu-kupu dalam Batik Enggros}

Tipikalis batik Enggros mempunyai keanekaragaman bentuk dan makna simbolis terkait, yang sudah turun-temurun dikenal oleh masyarakat Enggros. Salah satunya adalah hewan kupu-kupu. Yang sudah dipakai sejak dahulu kala oleh masyarakat tersebut. Mengapa mereka menjadikan kupu-kupu sebagai hewan kebesaran dari peranakan Iwo, karena kupu-kupu melambangkan perjalanan hidup yang penuh perjuangan hingga mencapai puncak keindahan hidup. Dimana tahapan hidup kuku-kupu diawali dari ulat yang berubah menjadi kepompong, lalu kulit kepompong terkoyak dan berubah menjadi kupu-kupu yang memiliki sayap beraneka ragam warna dan motif. "Itu menggambarkan perjuangan yang panjang dari yang buruk rupa sampai mencapai titik kecantikan, estetika tertinggi”. Tapi ketika menjadi kupu-kupu, masa hidupnya hanya sebentar.

Motif kupu-kupu dapat dijelaskan sebagaimana sifat dan karakternya seperti halnya hewan kupu-kupu yang memiliki keanekaragaman warna, mengapa masyarakat Enggros untuk marga peranakan Iwo menggunakan motif tersebut karena karakteristik dari hewan ini memperlihatkan sisi periang dari seseorang dengan warna-warninya. Selain itu dalam peranakan marga Iwo, kupu-kupu juga melambangkan sifat sukacita sementara makhluk bersayap ini selain menunjukkan keabadian juga kesenangan melimpah dan sukacita.

Selain menjelaskan sifat keperiangan, kupu-kupu dari marga peranakan Iwo juga mempunyai filosofi dengan adanya tanda-tanda. Jika kupu-kupu berwarna putih menandakan akan adanya tamu datang kerumah, dengan berita kebaikan. Sedangkan jika yang datang adalah kupu-kupu berwarna hitam, menandakan adanya berita kedukaan dari sanak keluarga atau orang-orang terdekat. Contoh penerapan motif kupu-kupu di batik Enggros dapat dilihat pada gambar 1.

\section{Motif Tifa pada Batik Enggros}

Tifa merupakan alat musik khas Indonesia bagian Timur, khususnya Maluku dan Papua. Alat musik ini terbuat dari sebatang kayu yang dikosongi atau dihilangi isinya dan pada salah satu sisi ujungnya ditutupi, dan biasanya penutupnya digunakan kulit rusa yang telah dikeringkan untuk menghasilkan suara yang bagus dan indah (Andibya 2008). Papua merupakan salah satu daerah yang kental dengan acara-acara ritual yang akan disandingkan dengan musik ritual sebagai pendukungnya. Irama yang dimainkan pastinya akan terasa sangat sakral dan akan menjadi prioritas utama di setiap kegiatan yang mereka 
gelar. Tifa merupakan salah satu alat musik yang wajib ada dan perannya akan cukup mendominasi. Hal ini dikarenakan tifa menentukan ritme dan menghasilkan tabuhantabuhan yang membuat ritual yang ada semakin khusuk. Tifa dijadikan motif pelengkap yang memiliki makna sebagai simbol dari kesakralan sebuah ritual. Contoh motif tifa dapat dilihat pada gambar 2 .

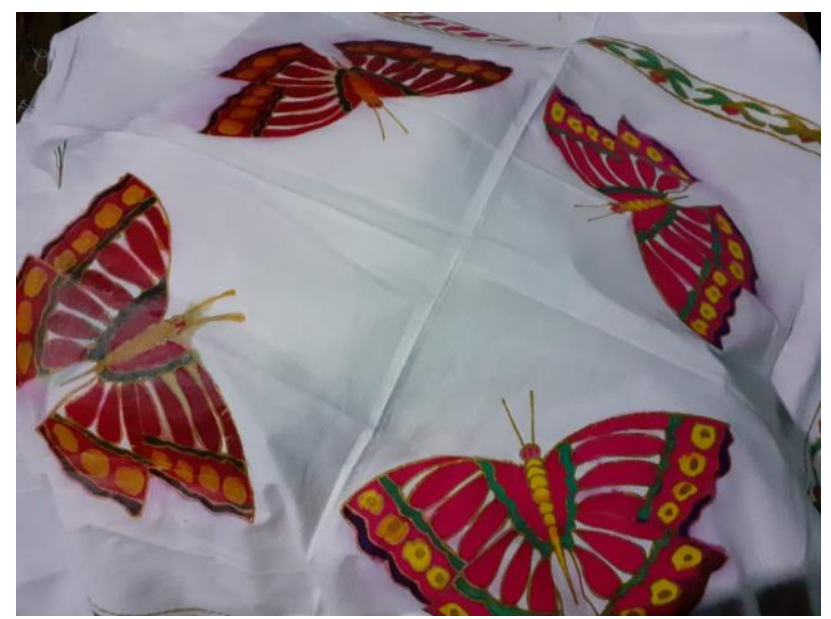

Gambar 1

Motif Kupu-kupu Batik Enggros

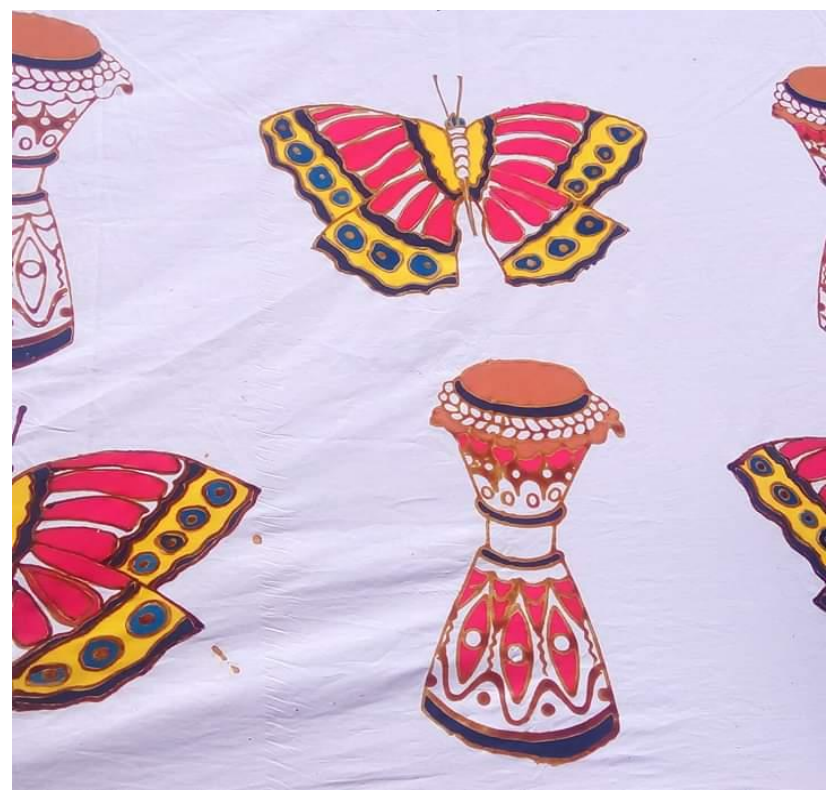

Gambar 2

Motif Kupu-kupu dan Tifa Batik Enggros

\section{Kesimpulan}

Batik Enggrost tergolong pada batik tradisi, penciptaan motif kupu-kupu pada batik Enggros dilatarbelakangi oleh kebesaran dari marga peranakan Iwo. Motif kupukupu diambil dari bentuk nyata hewan kupu-kupu sebagai hewan kebesaran dan motif pelengkap berupa alat music tifa yang distilasikan. Binatang kupu-kupu digunakan sebagai motif batik Enggros di lingkungan peranakan Iwo, memiliki makna karakteristik dari hewan ini memperlihatkan bahwa di lingkungan peranakan Iwo setiap pribadi 
memperlihatkan karakter periang dengan warna-warninya. Sedangkan motif pelengkap tifa memiliki makna sebagai simbol bahwa masyarakat Iwo adalah masyarakat yang berkarakter sakral, karena tifa adalah instrumen yang berperan penting dalam kesakralan sebuah ritual.

\section{Bibliografi}

Andibya, B.W. 2008. The Wonderful Islands Maluku: MembangunKembali Maluku Dengan Nilai-Nilai Dan KhazanahLokal, Serta Prinsip Entrepreneurial Government, BeragamPotensi Dan PeluangInvestasi. Berkeley: Gibon Books.

Fitno, Ade. 2015. "Kupu-Kupu Cinta." Kompasiana.com. 2015. https://www.kompasiana.com/adefitno/5500b39e8133110e51fa715e/kupu-kupu-cinta.

Moleong, Lexy J. 2000. MetodePenelitianKualitatif. Bandung: PT. RemajaRosdakarya.

Murtihadi. 1979. PengetahuanTeknologi Batik: Untuk SMIK. Jakarta: Direktorat Pendidikan MenengahKejuruan, Departemen Pendidikan dan Kebudayaan.

Prawira, SulasmiDarma. 2002. Warna: Teori Dan KreativitasPenggunaannya. 2nd ed. Bandung: PenerbitITB.

Riyanto, Didik. 1997. Proses Batik. Solo: CV Aneka.

Rossa, Terry De, and RahmatsyamLakoro. 2014. "PERANCANGAN DESAIN MOTIF BATIK BERKARAKTER KOTA SURABAYA." InstitutTeknologiSepuluh November. http://digilib.its.ac.id/ITS-paper-34021140003591/29300.

Sewan, Susanto. 1980. SeniKerajinan-Kerajinan Batik Indonesia. Yogyakarta: BalaiPenelitian Batik dan Kerajinan.

\section{Biografi}

Nathalia Dwijayanti adalah wanita energik yang berprofesi sebagai pengajar pada Institut Seni Budaya Indonesia (ISBI) Tanah Papua. Sekarang sedang melakukan studi pada Pascasarjana di Institut Seni Indonesia Surakarta. Ia menerima gelar sarjana seni dari Institut Kesenian Jakarta. Bidang yang ditekuni adalah kriya tekstil. Ia menaruh perhatian pada kekhasan seni tenun dari Nusa Tenggara Timur dan daerah Indonesia Timur lainnya. 